\title{
Analysis of glass from the post-Roman settlement Tonovcov grad (Slovenia) by PIXE-PIGE and LA-ICP-MS
}

\author{
Z. Šmit ${ }^{\mathrm{a}, \mathrm{b}}$ T. Milavec ${ }^{\mathrm{c}}$, H. Fajfar ${ }^{\mathrm{b}}$, Th. Rehren ${ }^{\mathrm{d}}$, J.W. Lankton ${ }^{\mathrm{e}}$, B. Gratuze ${ }^{f}$ \\ a: Faculty of Mathematics and Physics, University of Ljubljana, Jadranska 19, SI-1000 Ljubljana, \\ Slovenia \\ b: Jozef Stefan Institute, Jamova 39, SI-1001 Ljubljana, Slovenia \\ c: Department of Archaeology, Faculty of Arts, University of Ljubljana, Zavetiška 5, SI-1000 Ljubljana, \\ Slovenia \\ d: UCL Qatar, Education City, P.O. Box 23689, Doha, Qatar \\ e: UCL Institute of Archaeology, 31-34 Gordon Square, London WC1H OPY, UK \\ f: IRAMAT-Centre Ernest-Babelon, CNRS Université d'Orléans, 3D rue de la Ferollerie, 45071 Orléans \\ Cedex 2, France
}

\begin{abstract}
The combined PIXE-PIGE method was used for the analysis of 43 glass fragments from the archaeological site Tonovcov grad in western Slovenia, with 10 of these additionally being analysed by LA-ICP-MS. The glass objects were attributed to the Late Antique production of the 4th-7th $c$. AD, with two examples of early Roman glass and three glass beads, one of them presumably of oriental origin. The analysis showed typical natron-type glass, produced in the Levantine region around the river Belus, and a few examples of HIMT glass, which could be recognized also in several other recycled objects. Only one glass bead, found in Early Medieval context, was made of the ash of halophytic plants.
\end{abstract}

\section{Introduction}

The fortified settlement of Tonovcov grad is located on a steep isolated hill above the Soc a River near the modern city of Kobarid in western Slovenia; its position is strategic and controls the traffic towards the upper Soc ${ }^{2}$ a valley. In spite of this and sporadic remarks in older historic literature it was recognized as a site rather late, in 1991 [1]. In subsequent years, systematic excavations were performed, revealing several buildings, a water cistern and a complex of Early Christian churches. Though several finds indicate that the site was populated from prehistory and Early Roman period until the Carolingian and Medieval period, its main settlement phase is Late Antiquity and involves two sub-phases: the first in the second half of the 4th and beginning of the 5th century, and the second between the end of the 5th and beginning of the 7th century [2]. Among the finds, which are predominantly from these two periods, there are also numerous fragments of glass. The majority of them (118) were discovered in the so-called building 1 , situated on the slope below the church complex and dated to the second Late Antique phase. Typologically, they include stemmed goblets, footed beakers, beakers, bottles, lamps, plates, bowls and window glass. Elongated bubbles in the window glass indicate that it was produced by the cylinder technique. According to the dating based on the archaeological evidence, the glass of Tonovcov grad belongs to the period between the 4th 
and early 7th centuries; only two glass fragments can be typologically dated to an earlier period of 1st-3rd centuries [2].

Glass of the Late Antique period had already attracted several research interests of the analysts [322], though Tonovcov grad is the first Slovenian site to be analysed. The site where the closest analogies with Tonovcov grad are anticipated are San Martino di Ovaro, which is only $58 \mathrm{~km}$ away as the crow flies; however, several mountain ranges and passes make the ground communication between the two sites difficult. Numerous glass finds from San Martino di Ovaro were analyzed by PIXE [14]; the glass composition of Late Antique samples agreed well with the Levantine I glass samples according to Freestone [23], indicating intense commercial relations between Northern Italy and the raw glass production area in the Palestinian coast. A similar scheme of the glass from Tonovcov grad is expected.

\section{Experimental}

The glass objects were analyzed in air by a proton beam of $3 \mathrm{MeV}$ nominal energy, provided by the Tandetron accelerator of the Joz ef Stefan Institute in Ljubljana. Due to stopping in the exit window and about $1 \mathrm{~cm}$ wide air gap between the window and target, the projectile impact energy at the target was about $2.7 \mathrm{MeV}$. The intensity profile of the beam was Gaussian, with $0.8 \mathrm{~mm}$ full width at half maximum. A combined PIXE-PIGE method was applied. For PIXE, the exit window of $8 \mu \mathrm{m}$ aluminium foil was used, in order to avoid the presence of scattered high energy $X$-ray lines in the spectra. The path-length of induced X-rays in the air was about $5.7 \mathrm{~cm}$. Precise values of both air gaps (with an accuracy of $0.1 \mathrm{~mm}$ ) was determined by a series of measurements on known metal and simple chemical compound targets, using the argon signal induced in air as an internal standard [24]. Spacers made of nylon rods were used to keep the experimental geometry fixed. Two X-ray spectra were measured in each measuring spot. Using air as the only absorber, the lightest element detected was silicon. Running the measurement at a current of a few tenths of nA for about $500 \mathrm{~s}$, the counting statistics limited detection of elements heavier than iron. For detection of heavier elements, the detector was equipped with an additional absorber of $0.1 \mathrm{~mm}$ aluminium foil, while the proton current was increased to a few $\mathrm{nA}$ at a measuring time of 400-500 s. The two spectra were combined into one using the Ka line of iron for normalization.

The concentrations of $\mathrm{Na}, \mathrm{Mg}$ and $\mathrm{Al}$, essential elements for glass characterization, were determined according to their induced gamma ray emissions (PIGE). The exit window for PIGE measurements was a $2 \mathrm{Im}$ tantalum foil, which emits proton-induced gamma rays below $300 \mathrm{keV}$. The proton current was about $3 \mathrm{nA}$ and the measurements lasted about $30 \mathrm{~min}$. The proton current was measured by a thin wire mesh intersecting the beam; transmission of the mesh was $58 \%$ [25]. The gamma rays employed for the analysis were $440 \mathrm{keV}$ for $\mathrm{Na}, 585$ for $\mathrm{Mg}$ and $1014 \mathrm{keV}$ for Al. The latter line is also induced in $\mathrm{Mg}$, but with negligible intensity at proton energies above $2.4 \mathrm{MeV}$ [26]. Its production becomes important at lower energies, for example at $1.77 \mathrm{MeV}$ its production in $\mathrm{Mg}$ is $8 \%$ of that in $\mathrm{Al}$ [27], but the production in Al at $1.7 \mathrm{MeV}$ is only $0.3 \%$ of that at $2.4 \mathrm{MeV}$ [26]. We therefore estimate the $\mathrm{Mg}$ contribution of $1014 \mathrm{keV}$ line in our spectra was minute.

The concentrations of $\mathrm{Na}, \mathrm{Mg}$ and $\mathrm{Al}$ were determined according to the known values in the standard glass NIST 620, using the surface approximation [28]. As this approach requires the proton stopping power in the sample and standard, the unknown concentrations were determined by an iterative procedure, considering both X-ray and gamma-ray intensities simultaneously. The matrix effects for X-ray and gamma ray production were calculated individually for each iteration step. The sum of all metal oxides was normalized to unity. For monitoring the accuracy of the procedure, the 
sum of metal oxides was also calculated according to the X-ray yield of argon from the air. These values typically departed from unity within $\pm 10 \%$, though a few samples with irregular or corroded surfaces exhibited larger differences, up to $30 \%$. For control purposes, the standard glasses NIST 620 and 621 were analyzed periodically as unknown samples.

The concentration uncertainties for major elements were $\pm 5 \%$, but increased to $10-20 \%$ for trace elements close to their detection limits. A peculiar example was $\mathrm{Mg}$, whose detection limit was about $0.2 \%$ due to interference of its $585 \mathrm{keV}$ line with the line of $583 \mathrm{keV}$ from the natural background, and due to strong Compton background of sodium lines at 1634 and $1636 \mathrm{keV}$. The two effects imply that magnesium concentrations were uncertain by $10 \%$. The limit of detection for aluminium was about $20 \mu \mathrm{g} / \mathrm{g}$. For the heavier elements obtained from the X-ray spectra, the limits of detection between $\mathrm{Co}$ and $\mathrm{Zr}$ (and Pb with its L lines) were about $10 \mu \mathrm{g} / \mathrm{g}$, and for Sn and Sb they were about $50 \mu \mathrm{g} / \mathrm{g}$.

Ten samples were also selected accidentally from the set and analyzed by LA-ICP-MS at the CNRS/IRAMAT laboratory in Orléans. These values were used as a test of our procedures, but they also provided concentrations of several elements present in concentrations below $1 \mu \mathrm{g} / \mathrm{g}$ level.

\section{Results}

The analytical results obtained by the PIXE-PIGE method are shown in Table 1. Single zeros denote non-detected elements. Elemental concentrations are shown in the form of oxides, whose sum was normalized to unity. For iron we formally adopted the oxide form Fe2O3, which, however, does not exclude the presence of $\mathrm{FeO}$; the ratio of the two oxides determines the blue-green or yellow tint of glass $[4,16,29]$. The oxidation number of iron could not be detected by our methods.

The LA-ICP-MS values were first used for comparison with the PIXE-PIGE data. Table 2 shows the concentration ratios of representative elements obtained by both methods. The agreement is generally good, though some systematic differences are evident. Sodium values are generally $13 \%$ higher for PIGE, which is contrary to expectations, as the surface concentrations (probed by PIGE) should be somewhat smaller than the bulk values on account of surface leaching. The magnesium concentrations are also higher, though the magnesium data show prominent scattering, which is result of poor counting statistics and high background contribution close to the detection limit. Aluminium concentrations are also scattered by $10 \%$, though their mean is closer to unity, which excludes systematic normalization error in PIGE measurements. Among the X-ray determined concentrations, potassium values are overestimated between $20 \%$ and $95 \%$. The reasons for these differences cannot be explained by X-ray techniques only, as potassium neighbours, chlorine and calcium show very good agreement with the LA-ICP-MS data. The only possible reason could be improper subtraction of the X-ray background or interference of potassium Ka and argon Kb lines, but these effects would be detected at the analysis of NIST 620 glass standard. Systematic underestimation of PIXE values by $20 \%$ is observed for manganese and iron, however, small scattering of the iron data indicates the error was introduced by the calibration procedure. The concentrations of trace elements that were detected by LA-ICP-MS only are listed in Table 3; it is split into two parts, the first showing the contents of rare earths, and the second the remaining light and heavy elements.

\section{Discussion}

The data of Table 1 were first studied for characteristic grouping using the principal component analysis (Fig. 1) of the oxides $\mathrm{Na2O}, \mathrm{MgO}, \mathrm{Al} 2 \mathrm{O} 3, \mathrm{SiO} 2, \mathrm{~K} 2 \mathrm{O}, \mathrm{CaO}, \mathrm{TiO} 2$ and Fe2O3. The selection of 
oxides reflects basic properties of the glassmaking process of the raw glass, but excludes its discoloration and pigmentation. Fig. 1 shows that the glasses of Tonovcov grad form quite a compact group. Only three data depart considerably from the main group: two glass beads and one vessel (23592 goblet foot). Fig. 1 also reveals that the three lamps are quite similar to each other, but distant from the two fragments of early Roman glass. A noticeable feature is three samples marked by an oval, whose raw material is identified further in Figs. 3 and 4.

The type of the flux is typically identified in the bivariate MgO- K2O plot [14], as shown in Fig. 2. As expected, all investigated glass objects (except one) belong to natron-type glass, identified by MgO concentrations below $1.6 \%$ and $\mathrm{K} 2 \mathrm{O}$ concentrations below $1 \%$ [30]. The same three samples as identified in Fig. 1 largely depart from the main group: two glass beads and a goblet foot. One of the two beads (22304) shows an MgO content of 5.7\%, which qualifies it as glass made of the ash of halophytic plants. This type of glass appears in Europe regularly only after $800 \mathrm{AD}$ and its early examples represent import from the Byzantine and Islamic world [23]. The glass bead 22304 is indeed of the oriental type and may be related to the short Carolingian period phase of the site. The other two items (bead 23653 and goblet foot 23592) show a higher content of K2O (1.72 and 3.59\%, respectively). Such high $\mathrm{K} 2 \mathrm{O}$ concentrations are not uncommon among the Late Roman glass $[15,22,31]$ and may result, for example, from the presence of alkali feldspars in the glass batch. The main group of Fig. 2 also shows an interesting time structure. The two Early Roman glass samples $(23060 / 1,23007)$ are characterized by low MgO values around $0.5 \%$, while the 4 th -7 th century samples (lamps) contain $\mathrm{MgO}$ concentrations around 1.5\%. Similar high MgO values were observed in the 7th century glass from Crypta Balbi in Rome [4]; lower MgO concentrations were found for the 8th c. glass from the same site, which may be explained by a higher content of recycled earlier glass in the objects [5].

Production places of primary raw glass are identified according to the calcareous component of the siliceous sand and the admixture of aluminium oxides [23]. In Fig. 3, we plotted results of our measurements together with the elemental ranges found in the literature; for the sake of clarity we have limited ourselves to the compositional groups that coincide with our measurements only. Group 3 of Foy [11] designates glass production in the Levantine area around the Belus River in a rather broad time period between the 3rd c. BC and 9th c AD. The subgroup of group 3 involves early Roman glass of the Imperial period (we denote it as 3/3.1-3.3 as it was derived from the group 3 subtracting the post-Roman groups 3.1-3.3 [11]); this group nicely coincides with the two groups of coloured glass from the shipwreck of Iulia Felix [32]. Group 4 of Foy [11,33] designates glass of the $2 \mathrm{nd}$ and $3 \mathrm{rd} \mathrm{c}$. AD that was decolorized by antimony. The origin of group 4 remained unknown until recently; isotopic studies of glass from the Ouest Embiez and lulia Felix shipwrecks suggest this glass was also made in Palestine, but likely in a different workshop [34]. All these groups are shown as ellipses with the axes that measure four standard deviations. Beside this, Fig. 3 also shows the Late Roman glass groups as defined by Freestone [23]: HIMT and Levantine I and II. These groups are plotted as rectangles, following the method of Zucchiatti [14]. We can see that nearly all our samples coincide with Foy's group 3 and Freestone's Levantine I glass, so they originate from the Palestinian glassmaking area. A slight shift between the group 3 and Levantine I denotes a minor variation of the glass composition with time, as the Levantine I glass is dated to the 5th-7th c. AD [23]. The reason for this variation may be geological or anthropogenic, i.e., gradual moving of the production site. As the analyzed glass selection involves only two examples of early Roman glass, it is not surprising that the region of group 4 in Fig. 3 remained empty. 
The only example of window glass (23060/4) is located at the low Al2O3 border of Levantine I glass; this type of glass was widely used for glass manufacture in different geographic regions $[14,35,36]$. The three glass samples isolated in Fig. 1 contain the lowest $\mathrm{CaO}$ concentrations and are located in the cross-section of the group 3 and HIMT in Fig. 3. These samples (23054, 23674 and 23424) contain more than $0.46 \mathrm{TiO} 2,1.76 \% \mathrm{Fe} 2 \mathrm{O} 3$ and $1.38 \% \mathrm{MnO}$, which characterizes them as HIMT glass. This glass was first observed by Freestone among the glasses of Carthage, but it appeared also among the glasses of Aoste [29] and in south France [10]. In Britain, HIMT glass appeared as early as $330 \mathrm{AD}$ and represents the most wide-spread glass type in Late Antiquity [37]. For the window glass, it was recognized among the glass fragments from the Theoderic's villa in Galeata [17]. Glass belonging to the Levantine I and HIMT types was also discovered among the Early Byzantine glass in Ganzirri, Sicily [16]. The sand source of HIMT glass is different from the Palestinian sources, but has not been identified yet; Egypt is one of the possible locations.

The distinction of the HIMT glass from the Levantine I is evident in Fig. 4, which shows the contents of siliceous sand impurities $\mathrm{Ti}, \mathrm{Sr}$ and $\mathrm{Zr}$. In Fig. 4a we observe linear correlation between $\mathrm{TiO} 2$ and Fe203, which indicates mineral origin of both elements. Exceptions are two glass beads (23653, 23654) and HIMT glass that are evidently of different origins. SrO concentrations are above $440 \mathrm{lg} / \mathrm{g}$, which is consistent with the composition of the maritime siliceous sand that contains shell fragments as a source of $\mathrm{CaO}[23]$.

HIMT glass is characterized by a high content of zirconium [9], which is also observed in our case (Fig. 4c). Two correlation lines are further observed in Fig. 4c, which clearly indicate two sand sources. The glasses arranged around the HIMT line contain lower ZrO2 values and were very likely recycled using HIMT glass.

The rare earth pattern is shown in Fig. 5, normalizing the elemental concentrations to the mean values encountered in the upper continental crust [38]. It seems there is no significant time structure, except the values for the 4 th-5th c. being higher than those in the later glass. However, this is on account of the sample 23054, which is the only example of HIMT glass in Table 3. In comparison with the glasses from Ganzirri, Sicily [16], glass of the 5th-7th c. from Tonovcov grad corresponds to group 1 of Ganzirri; this is understandable, as the glass in both cases is of Levantine I type. Group 2 of Ganzirri represents HIMT glass; in our case it is sample 23054 that fits into this group. The rare earth pattern from both sites is therefore matching and confirms distinction between Levantine I and HIMT glass according to the rare earth elements.

Summarizing, there are 26 samples identified as Levantine I, while another 11 show significant similarities to Roman blue/green glass. Of these, the two early Roman samples stand out with a lower strontium content relative to the lime content; the remaining nine samples fall into two nearly equally strong groups of low and elevated titania, respectively. It is possible that the four samples with higher titania include a proportion of recycled HIMT glass in them; most other oxide concentrations are also consistent with this, except for magnesia, which is slightly too high in the mixed group compared to HIMT. Thus, it is also possible that the four samples with elevated titania content were produced from a less pure sand, due to the before-mentioned geological or anthropogenic changes in sand source.

For decoloration, $\mathrm{MnO}$ was used for all investigated glasses. $\mathrm{MnO}$ concentrations are spanning an interval between $0.23 \%$ and $2.14 \%$, which agrees with the decoloration method in group 3 . The concentrations of $\mathrm{Sb} 2 \mathrm{O} 3$ are typically below $0.06 \%$, which may indicate values not added on purpose, but the presence of antimony as the result of recycling; the source of antimony may be opaque tesserae added to the glass batch [4]. Only one sample of early Roman glass (23060/1) 
contains a higher content of Sb2O3 of $0.13 \%$ : however, even this value is not high enough to denote intentional decoloration by antimony. For antimony oxide, the concentrations added on purpose should be higher than $0.2 \%$ [30] and for manganese higher than $0.5 \%$ [39]. The antimony content in the fragment $23060 / 1$ is then result of recycling during an early Roman period.

Among the other elements used for pigmentation, three blue samples (two beads and an early Roman cup) were pigmented by a combination of cobalt and copper oxides on $0.1 \%$ level. The red colour of the bead 23653 was attained by addition of $2.5 \% \mathrm{CuO}$; this bead also contains $1.8 \% \mathrm{SnO} 2$, which may indicate bronze as a copper source.

The recycling history may also be followed according to the content of heavy elements that increase with the number of recycling steps. The contents of $\mathrm{Cu}$ and $\mathrm{Zn}$ suggest similarity between the three lamps, which may indicate production in the same secondary workshop (see Fig. 6).

\section{Conclusion}

The glasses of Tonovcov grad show two characteristic glass sources: glass from the Levantine area near the River Belus, which represents the majority of the investigated samples, and a small group of three samples that are characterized as HIMT glass according to their high titanium, iron and manganese contents. Further, the contents of zirconium and strontium reveal that certain glasses were recycled with the HIMT glass. The presence of HIMT glass makes distinction between the glass inventories of Tonovcov grad and San Martino di Ovaro, which is archaeologically and geographically its closest (analyzed) parallel. The joint occurrence of Levantine I and HIMT glass makes the glass inventory of Tonovcov grad more similar to that of Ganzirri in Sicily. This shows that the settlement of Tonovcov grad retained strong economic and political contacts with the Mediterranean world. However, the large fractions of Levantine I glass make the three sites specifically different from the Western Europe, which was main consumer of HIMT glass. This indicates specific trade routes in Late Antiquity. The production of Levantine I glass probably boomed after that of HIMT glass, in a period when the economic connections between the Mediterranean and Atlantic Europe were already in decline.

\section{References}

[1] S. Ciglenec `ki, Z. Modrijan, T. Milavec, Late Antique fortified settlement Tonovcov grad near Kobarid, Settlement remains and interpretation, Opera Instituti Archaeologici Sloveniae (Ljubljana) 23 (2011).

[2] Z. Modrijan, T. Milavec, Late Antique fortified settlement Tonovcov grad near Kobarid, Finds, Opera Instituti Archaeologici Sloveniae (Ljubljana) 24 (2011).

[3] I.C. Freestone, Y. Gorin-Rosen, M.J. Hughes, Primary glass from Israel and the production of glass in Late Antiquity and the early Islamic period, in: M.-D. Nenna (Ed.), La route du verre Ateliers primaries et secondaires du second millénaire av. J.-C. au Moyen Âge, Maison de I'Orient Méditerranéen-Jean Pouillox, Lyon, 2000, pp. 65-83.

[4] P. Mirti, A. Lepora, L Saguì Scientific analysis of seventh-century glass fragments from the Crypta Balbi in Rome, Archaeometry 42 (2000) 359-374.

[5] P. Mirti, P. Davit, M. Gulmini, L Sagui glass fragments from the Crypta Balbi in Rome: the composition of eight-century fragments, Archaeometry 43 (2001) 491-502.

[6] R. Bertoncello, L. Milanese, U. Russo, D. Pedron, P. Guerriero, S. Barison, Chemistry of cultural glasses: the early medieval glasses of Monselice's hill (Padova, Italy), J. Non-Cryst. Solids 306 (2002) 249-262. 
[7] I.C. Freestone, M. Ponting, M.J. Hughes, The origins of Byzantine glass from Maroni Petrera Cyprus, Archaeometry 44 (2002) 257-272.

[8] M. Verità, A. Renier, S. Zecchin, Chemical analyses of ancient glass findings excavated in the Venetian lagoon, J. Cult. Herit. 3 (2002) 261-271.

[9] A. Aerts, B. Velde, K. Janssens, W. Dijkman, Change in silica sources in Roman and post-Roman glass, Spectrochimica Acta B 58 (2003) 659-667.

[10] M. Picon, M. Vichy, D'Orient en Occident: I'origine du verre à l'époque romaine et Durant le haut Moyen Âge, in D. Foy, M.-D. Nenna (Eds.) Échange et commerce du verre dans le monde antique. Actes du colloque de l'Association Française pour l'Archéologie du Verre, Aix-enProvence et Marseille 2001, Éditions Monique Mergoil, Montagnac (2003), pp. 17-31.

[11] D. Foy, M. Picon, M. Vichy, V. Thirion-Merle, Caractérisation des verres de la fin de l'Antiquité en Méditerranée occidentale: l'emergence de nouveaux courants commerciaux., in D. Foy, M.-D. Nenna (Eds.) Échange et commerce du verre dans le monde antique. Actes du colloque de I'Association Française pour l'Archéologie du Verre, Aix-en-Provence et Marseille 2001, Éditions Monique Mergoil, Montagnac (2003), pp. 41-85.

[12] M. Uboldi, M. Verità, Scientific Analyses of Glasses from Late Antique and Early Medieval Archaeological Sites in Northern Italy, J. Glass Stud. 45 (2003) 115- 137.

[13] B. Gómez-Tubío, M.Á. Ontalba Salamanca, I. Ortega-Feliu, M.Á. Respaldiza, F. Amores Carredano, D. González-Acuña, PIXE-PIGE analysis of late Roman fragments, Nucl. Instr. Meth. B 249 (2006) 616-621.

[14] A. Zucchiatti, L. Canonica, P. Prati, A. Cagnana, S. Roascio, A. Climent-Font, PIXE analysis of V-XVI century glasses from the archaeological site of San Martino di Ovaro (Italy), J. Cult. Herit. 8 (2007) 307-314.

[15] Ž . Šmit, D. Jezeršek, T. Knific, J. Istenic ², PIXE-PIGE analysis of Carolingian period glass from Slovenia, Nucl. Instr. Meth. B 267 (2009) 121-124.

[16] R. Arletti, C. Giacobbe, S. Quartieri, G. Sabatino, G. Tigano, M. Triscari, G. Vezzalini, Archaeometrical investigation of Sicilian early Byzantine glass chemical and spectroscopic data, Archaeometry 52 (2010) 99-114.

[17] R. Arletti, G. Vezzalini, S. Benati, L. Mazzeo Saracino, A. Gamberini, Roman window glass, a comparison of findings from three different Italian sites, Archaeometry 52 (2010) 252-271.

[18] J. Drauschke, S. Greiff, Chemical aspects of Byzantine glass from Caric ${ }^{\sim}$ in grad/ lustiniana Prima (Serbia), in: J. Drauschke, D. Keller (Eds.), Glass in Byzantium - Production, Usage, Analyses, Verlag des Römisch-Germanisches Zentralmuseum, Mainz, 2010, pp. 25-46.

[19] F. Mathis, G. Othmane, O. Vrielynck, H. Calvo del Castillo, G. Chêne, T. Dupois,

D. Strivay, Combined PIXE/PIGE and IBIL with external beam applied to the analysis of Merovingian glass beads, Nucl. Instr. Meth. B 268 (2010) 2078- 2082.

[20] Th. Rehren, F. Marii, N. Schibille, C. Swann, L. Stanford, Glass supply and circulation in early Byzantine southern Jordan, in: J. Drauschke, D. Keller (Eds.), Glass in Byzantium - Production, Usage, Analyses, RGZM, Mainz, 2010, pp. 65-81.

[21] K.H. Wedepohl, K. Simon, A. Kronz, Data on 61 chemical elements for the characterization of three major glass compositions in Late Antiquity and the Middle Ages, Archaeometry 53 (2011) 81-102.

[22] Z`. Šmit, T. Knific, D. Jezeršek, J. Istenic ${ }^{2}$, Analysis of early medieval glass beads - Glass in the transition period, Nucl. Instr. Meth. B 278 (2012) 8-14. 
[23] I.C. Freestone, The provenance of ancient glass through compositional analysis, Material Research Society Proceeding 852 (2005) 008.1.1-008.1.13.

[24] Z` . Šmit, M. Uršič , P. Pelicon, T. Trček-Pečak, B. Šeme, A. Smrekar, I. Langus, I. Nemec, K, Kavkler, Concentration profiles in paint layers studied by differential PIXE, Nucl. Instr. Meth. B 266 (2008) 2047-2059.

[25] D. Jezeršek, Ž . Šmit, P. Pelicon, External beamline setup for plated target investigation, Nucl. Instr. Meth. B 268 (2010) 2006-2009.

[26] J.-P. Hirvonen, R. Lappalainen, Particle-Gamma Data, in: J.R. Tesmer, M. Nastasi (Eds.), Handbook of Modern Ion Beam Materials Analysis, Materials Research Society, Pittsburgh, 1995, pp. 573-613.

[27] A. Savidou, X. Aslanoglou, T. Paradellis, M. Pilakouta, Proton induced thick target c-yields of light nuclei at the energy region Ep = 1.0-4.1 MeV, Nucl. Instr. Meth. B 152 (1999) 12-18.

[28] A. Climent-Font, A. Muñoz-Martin, M.D. Ynsa, A. Zucchiatti, Quantification of sodium in ancient Roman glasses with ion beam analysis, Nucl. Instr. Meth. B 266 (2008) 640-648.

[29] P. Mirti, A. Casoli, L. Appolonia, Scientific analysis of Roman glass from Augusta Praetoria, Archaeometry 35 (1993) 225-240.

[30] E.V. Sayre, R.W. Smith, Compositional categories of ancient glass, Science 133 (1961) 18241826.

[31] R. Arletti, G. Vezzalini, S. Biaggio-Simona, F. Maselli Scotti, Archaeometrical studies of Roman imperial age glass from Canton Ticino, Archaeometry 50 (2008) 606-626.

[32] A. Silvestri, The colored glass of Iulia Felix, J. Arch. Sci 35 (2008) 1489-1501.

[33] V. Thirion-Merle, M. Vichy, Annexe - Note sur la composition chimique des verres de l'épave des Embiez, Revue Archéologique de Narbonnaise 40 (2007) 266-268.

[34] M. Ganio, S. Boyen, D. Brems, R. Scott, D. Foy, K. Latruwe, G. Molin, A. Silvestri, F. Vanhaecke, P. Degryse, Trade routes across the Mediterranean: a $\mathrm{Sr} / \mathrm{Nd}$ isotopic investigation on Roman colourless glass, Glass Technol.: Eur. J. Glass Sci. Technol. 53 (2012) 217-224.

[35] S. Wolf, C.M. Kessler, W.B. Stern, Y. Gerber, The composition and manufacture of early medieval coloured window glass from Sion (Valais, Switzerland) - a Roman glassmaking tradition or innovative craftsmanship, Archaeometry 47 (2005) 361-380.

[36] N. Schibille, F. Marii, Th. Rehren, Characterization and provenance of Late Antique window glass from the Petra Church Jordan, Archaeometry 50 (2008) 627-642.

[37] H.E. Foster, C.M. Jackson, The composition of 'naturally colored' late Roman vessel glass from Britain and the implications for models of glass production and supply, J. Arch. Sci. 36 (2009) 189-204.

[38] K.H. Wedepohl, The composition of the continental crust, Geochim. Cosmochim. Acta 59 (1995) 1217-1232.

[39] C.M. Jackson, Making colourless glass in the Roman period, Archaeometry 47 (2005) 763-780. 


\begin{tabular}{|c|c|c|c|c|c|c|c|c|c|c|c|c|c|c|c|c|c|c|c|c|c|c|c|}
\hline No. & & $\mathrm{Na}_{2} \mathrm{O}$ & $\mathrm{MgO}$ & $\mathrm{A} 1203$ & $\mathrm{SiO}_{2}$ & $\mathrm{SO}_{3}$ & $\mathrm{Cl}$ & $\mathrm{K}_{2} \mathrm{O}$ & $\mathrm{CaO}$ & $\mathrm{TiO}_{2}$ & $\mathrm{MnO}$ & Fe203 & $\mathrm{CoO}$ & $\mathrm{NiO}$ & $\mathrm{CuO}$ & $\mathrm{ZnO}$ & $\mathrm{Br}$ & $\mathrm{Rb}_{2} \mathrm{O}$ & $\mathrm{SrO}$ & $\mathrm{ZrO}_{2}$ & $\mathrm{SnO}_{2}$ & Sb203 & $\mathrm{PbO}$ \\
\hline 23654 & Quadruple glass bead & 18.5 & 1.11 & 2.66 & 65.3 & 0.77 & 1.04 & 0.90 & 6.62 & 0.16 & 0.81 & 1.56 & 0.100 & 0.0087 & 0.1137 & 0.0069 & 0.0012 & 0.0013 & 0.056 & 0.023 & 0 & 0.016 & 0.124 \\
\hline 23653 & Small glass bead (red) & 15.0 & 0.98 & 2.59 & 54.6 & 0.29 & 1.26 & 1.72 & 9.00 & 0.23 & 0.42 & 2.29 & 0 & 0.0140 & 2.5160 & 0.8526 & 0.0104 & 0 & 0.103 & 0.009 & 1.32 & 0 & 6.679 \\
\hline 22304 & Glass bead (blue) & 14.3 & 5.70 & 1.80 & 65.3 & 0.53 & 0.69 & 3.19 & 6.52 & 0.08 & 0.51 & 0.77 & 0.067 & 0.0035 & 0.0806 & 0.3622 & 0.0010 & 0 & 0.053 & 0.012 & 0.011 & 0 & 0.049 \\
\hline $23060 / 1$ & Bluish glass & 17.5 & 0.48 & 2.27 & 69.3 & 0.53 & 0.96 & 0.84 & 6.91 & 0.08 & 0.40 & 0.37 & 0 & 0.0013 & 0.0228 & 0.0029 & 0.0004 & 0.0009 & 0.045 & 0.006 & 0 & 0.129 & 0.054 \\
\hline 23007 & Cup (early; blue) & 18.1 & 0.63 & 2.31 & 68.5 & 0.51 & 1.05 & 0.69 & 7.12 & 0.05 & 0.23 & 0.60 & 0.057 & 0.0027 & 0.1277 & 0.0072 & 0.0006 & 0.0014 & 0.044 & 0.004 & 0.008 & 0.024 & 0.018 \\
\hline 23014 & Lamp & 17.7 & 1.42 & 2.53 & 63.8 & 0.64 & 0.84 & 0.87 & 9.21 & 0.14 & 1.55 & 1.04 & 0 & 0.0027 & 0.0068 & 0.0037 & 0.0017 & 0 & 0.094 & 0.012 & 0 & 0.028 & 0.015 \\
\hline 23426 & Lamp (church) & 17.8 & 1.30 & 2.65 & 65.3 & 0.60 & 0.77 & 0.95 & 7.54 & 0.14 & 1.78 & 1.12 & 0 & 0.0030 & 0.0075 & 0.0037 & 0.0017 & 0.0008 & 0.085 & 0.011 & 0 & 0 & 0.013 \\
\hline 23427 & Lamp (church) & 19.7 & 1.30 & 3.17 & 62.3 & 0.72 & 0.80 & 0.80 & 8.54 & 0.15 & 1.41 & 0.93 & 0 & 0.0032 & 0.0129 & 0.0037 & 0.0016 & 0.0010 & 0.094 & 0.013 & 0 & 0.015 & 0.028 \\
\hline $23060 / 2$ & Goblet foot & 17.7 & 1.13 & 3.14 & 65.7 & 0.64 & 0.74 & 0.80 & 7.82 & 0.13 & 1.33 & 0.76 & 0 & 0.0016 & 0.0066 & 0.0020 & 0.0015 & 0.0009 & 0.079 & 0.011 & 0 & 0.020 & 0.012 \\
\hline $23060 / 3$ & Fire-rounded rim & 17.4 & 1.41 & 2.48 & 64.8 & 0.54 & 0.69 & 1.11 & 8.94 & 0.14 & 1.51 & 0.81 & 0 & 0.0020 & 0.0079 & 0.0027 & 0.0010 & 0.0008 & 0.082 & 0.008 & 0 & 0.013 & 0.010 \\
\hline 23017 & Glass handle & 18.6 & 1.03 & 2.61 & 66.3 & 0.49 & 0.85 & 0.86 & 6.51 & 0.23 & 0.99 & 1.27 & 0 & 0.0021 & 0.0064 & 0.0029 & 0.0014 & 0.0011 & 0.056 & 0.016 & 0 & 0 & 0.009 \\
\hline 23034 & Fire-rounded rim & 20.5 & 1.29 & 2.34 & 65.9 & 0.74 & 0.78 & 0.54 & 6.24 & 0.10 & 0.93 & 0.57 & 0 & 0.0013 & 0.0038 & 0.0018 & 0.0011 & 0.0006 & 0.055 & 0.009 & 0 & 0.004 & 0.005 \\
\hline 23055 & Bottle & 19.4 & 1.49 & 2.65 & 63.8 & 0.64 & 0.84 & 0.68 & 8.10 & 0.14 & 1.32 & 0.76 & 0 & 0.0015 & 0.0042 & 0.0021 & 0.0011 & 0.0007 & 0.074 & 0.010 & 0 & 0.016 & 0.005 \\
\hline 23074 & Beaker base & 18.9 & 0.94 & 2.27 & 67.4 & 0.46 & 0.97 & 0.54 & 6.17 & 0.19 & 0.85 & 1.08 & 0 & 0.0016 & 0.0038 & 0.0021 & 0.0012 & 0.0011 & 0.050 & 0.013 & 0 & 0.004 & 0.005 \\
\hline 23069 & Balsamarium (base) & 20.2 & 0.70 & 2.19 & 65.5 & 0.70 & 0.77 & 0.63 & 7.36 & 0.11 & 1.10 & 0.64 & 0 & 0.0018 & 0.0046 & 0.0031 & 0.0010 & 0.0005 & 0.073 & 0.008 & 0 & 0.016 & 0.004 \\
\hline 23026 & Fire-rounded rim & 17.5 & 1.33 & 2.51 & 64.0 & 0.65 & 0.79 & 0.94 & 9.46 & 0.14 & 1.50 & 0.85 & 0 & 0.0013 & 0.0096 & 0.0024 & 0.0014 & 0.0006 & 0.092 & 0.010 & 0.005 & 0.014 & 0.016 \\
\hline 23071 & Goblet foot & 20.8 & 0.72 & 2.38 & 66.3 & 0.67 & 0.99 & 0.55 & 5.95 & 0.11 & 0.77 & 0.65 & 0 & 0.0013 & 0.0093 & 0.0020 & 0.0010 & 0.0009 & 0.048 & 0.008 & 0 & 0 & 0.011 \\
\hline 23078 & Plate & 15.8 & 1.07 & 3.14 & 67.8 & 0.59 & 0.80 & 0.86 & 8.75 & 0.06 & 0.75 & 0.34 & 0 & 0.0009 & 0.0010 & 0.0016 & 0.0006 & 0.0011 & 0.057 & 0.005 & 0 & 0 & 0.002 \\
\hline 23082 & Goblet foot & 20.6 & 1.19 & 2.57 & 64.0 & 0.67 & 0.93 & 0.65 & 7.33 & 0.12 & 1.17 & 0.61 & 0 & 0.0007 & 0.0047 & 0.0018 & 0.0014 & 0.0010 & 0.065 & 0.009 & 0 & 0.023 & 0.007 \\
\hline 23009 & Fire-rounded rim & 17.4 & 1.42 & 2.40 & 64.4 & 0.62 & 0.91 & 0.90 & 9.08 & 0.14 & 1.49 & 1.03 & 0 & 0.0023 & 0.0053 & 0.0033 & 0.0016 & 0.0009 & 0.087 & 0.010 & 0 & 0.028 & 0.013 \\
\hline 23068 & Beaker base & 20.4 & 1.00 & 2.17 & 65.5 & 0.77 & 0.85 & 0.62 & 7.26 & 0.09 & 0.73 & 0.51 & 0 & 0.0009 & 0.0016 & 0.0016 & 0.0015 & 0.0011 & 0.072 & 0.008 & 0 & 0 & 0.001 \\
\hline 23033 & Bottle rim & 20.0 & 1.45 & 2.34 & 66.1 & 0.51 & 0.92 & 0.52 & 6.49 & 0.25 & 0.46 & 0.78 & 0 & 0.0010 & 0.0028 & 0.0020 & 0.0009 & 0.0008 & 0.058 & 0.018 & 0 & 0 & 0.004 \\
\hline 23400 & Goblet foot & 19.0 & 0.98 & 2.21 & 64.8 & 0.67 & 0.90 & 0.84 & 8.59 & 0.13 & 1.01 & 0.71 & 0 & 0.0009 & 0.0038 & 0.0028 & 0.0011 & 0.0009 & 0.077 & 0.009 & 0 & 0.026 & 0.005 \\
\hline 23083 & Goblet foot & 20.5 & 0.54 & 2.12 & 67.4 & 0.59 & 0.94 & 0.43 & 6.42 & 0.07 & 0.61 & 0.32 & 0 & 0.0009 & 0.0019 & 0.0013 & 0.0009 & 0.0005 & 0.052 & 0.005 & 0 & 0 & 0.002 \\
\hline 23607 & Goblet foot & 20.6 & 0.39 & 2.31 & 67.0 & 0.73 & 0.94 & 0.77 & 5.96 & 0.08 & 0.68 & 0.38 & 0 & 0.0011 & 0.0030 & 0.0042 & 0.0013 & 0.0009 & 0.049 & 0.006 & 0 & 0 & 0.001 \\
\hline 23030 & Cup Foy $21 a$ & 19.7 & 0.83 & 1.89 & 67.2 & 0.72 & 1.10 & 0.51 & 6.83 & 0.07 & 0.70 & 0.36 & 0 & 0.0009 & 0.0022 & 0.0016 & 0.0009 & 0.0005 & 0.054 & 0.005 & 0 & 0 & 0.001 \\
\hline 22994 & $\operatorname{Rim}$ & 17.9 & 1.52 & 2.95 & 63.1 & 0.57 & 0.66 & 1.04 & 9.88 & 0.15 & 1.14 & 0.85 & 0 & 0.0012 & 0.0027 & 0.0025 & 0.0007 & 0.0009 & 0.090 & 0.011 & 0 & 0 & 0.002 \\
\hline 23029 & Goblet wall & 17.8 & 1.45 & 2.76 & 63.3 & 0.67 & 0.66 & 0.85 & 9.70 & 0.15 & 1.42 & 0.91 & 0 & 0.0013 & 0.0037 & 0.0026 & 0.0009 & 0.0011 & 0.092 & 0.012 & 0 & 0 & 0.004 \\
\hline 23054 & Base (olive color) & 17.7 & 1.23 & 2.42 & 66.8 & 0.41 & 0.87 & 0.67 & 5.75 & 0.52 & 2.12 & 1.38 & 0 & 0.0016 & 0.0056 & 0.0036 & 0.0011 & 0 & 0.054 & 0.036 & 0 & 0 & 0.003 \\
\hline 23576 & Goblet rim & 19.8 & 1.37 & 2.87 & 63.1 & 0.57 & 0.82 & 0.91 & 7.98 & 0.14 & 1.45 & 0.80 & 0 & 0.0022 & 0.0072 & 0.0031 & 0.0016 & 0.0010 & 0.083 & 0.009 & 0 & 0 & 0.010 \\
\hline 23594 & Goblet rim & 18.3 & 1.41 & 2.74 & 65.7 & 0.59 & 0.86 & 0.75 & 7.12 & 0.18 & 1.13 & 0.87 & 0 & 0.0011 & 0.0125 & 0.0037 & 0.0009 & 0.0009 & 0.058 & 0.012 & 0 & 0.056 & 0.018 \\
\hline 23674 & Cut rim & 18.7 & 0.92 & 2.70 & 65.5 & 0.51 & 0.94 & 0.48 & 6.27 & 0.50 & 1.76 & 1.49 & 0 & 0.0011 & 0.0057 & 0.0030 & 0.0011 & 0 & 0.060 & 0.037 & 0 & 0 & 0.002 \\
\hline 23424 & Cut rim & 17.0 & 1.09 & 2.91 & 66.5 & 0.42 & 0.97 & 0.59 & 6.25 & 0.46 & 2.05 & 1.58 & 0 & 0.0011 & 0.0063 & 0.0034 & 0.0009 & 0 & 0.053 & 0.030 & 0 & 0 & 0.001 \\
\hline 23501 & Goblet rim & 19.8 & 1.31 & 2.78 & 62.5 & 0.64 & 0.90 & 0.81 & 8.87 & 0.15 & 1.21 & 0.84 & 0 & 0.0014 & 0.0080 & 0.0034 & 0.0011 & 0 & 0.083 & 0.010 & 0 & 0.020 & 0.035 \\
\hline 23502 & Goblet rim & 18.3 & 1.30 & 2.65 & 64.6 & 0.67 & 0.81 & 1.01 & 7.64 & 0.15 & 1.42 & 1.16 & 0 & 0.0025 & 0.0429 & 0.0043 & 0.0014 & 0.0012 & 0.083 & 0.010 & 0 & 0.039 & 0.047 \\
\hline 23425 & Goblet foot & 17.8 & 1.29 & 2.23 & 65.5 & 0.60 & 0.81 & 0.70 & 8.93 & 0.12 & 1.24 & 0.65 & 0 & 0.0011 & 0.0034 & 0.0016 & 0.0008 & 0 & 0.086 & 0.010 & 0 & 0.023 & 0.004 \\
\hline 23498 & Goblet foot & 17.9 & 1.68 & 2.48 & 65.3 & 0.58 & 0.82 & 1.01 & 7.63 & 0.15 & 1.58 & 0.71 & 0 & 0.0016 & 0.0046 & 0.0048 & 0.0010 & 0.0010 & 0.077 & 0.011 & 0 & 0.013 & 0.008 \\
\hline 23433 & Beaker base & 17.5 & 1.41 & 2.68 & 65.0 & 0.68 & 0.77 & 0.97 & 7.36 & 0.14 & 2.14 & 1.13 & 0 & 0.0027 & 0.0082 & 0.0037 & 0.0015 & 0 & 0.094 & 0.011 & 0 & 0 & 0.013 \\
\hline 23497 & Beaker base & 20.1 & 1.10 & 2.49 & 64.4 & 0.58 & 0.79 & 0.82 & 7.42 & 0.11 & 1.26 & 0.70 & 0 & 0.0025 & 0.0054 & 0.0033 & 0.0013 & 0.0008 & 0.073 & 0.007 & 0 & 0 & 0.011 \\
\hline 23829 & Goblet rim & 19.8 & 1.42 & 2.38 & 63.8 & 0.59 & 0.85 & 0.87 & 7.84 & 0.13 & 1.36 & 0.74 & 0 & 0.0019 & 0.0060 & 0.0029 & 0.0014 & 0 & 0.081 & 0.008 & 0 & 0 & 0.012 \\
\hline 23828 & Goblet foot & 18.3 & 1.44 & 2.61 & 62.7 & 0.68 & 0.60 & 0.93 & 9.89 & 0.14 & 1.26 & 1.27 & 0 & 0.0019 & 0.0054 & 0.0032 & 0.0009 & 0 & 0.110 & 0.010 & 0 & 0 & 0.013 \\
\hline 23592 & Goblet foot & 17.1 & 1.04 & 2.91 & 64.6 & 0.43 & 0.74 & 3.59 & 7.35 & 0.11 & 1.24 & 0.71 & 0 & 0.0013 & 0.0065 & 0.0019 & 0.0013 & 0 & 0.074 & 0.010 & 0 & 0.024 & 0.011 \\
\hline $23060 / 4$ & Window glass & 17.3 & 0.99 & 2.48 & 66.1 & 0.49 & 0.69 & 0.66 & 8.79 & 0.13 & 1.46 & 0.77 & 0 & 0.0020 & 0.0054 & 0.0019 & 0.0009 & 0.0008 & 0.081 & 0.011 & 0 & 0.029 & 0.009 \\
\hline
\end{tabular}

Table 1

Composition of the glass from Tonovcov grad - concentrations of oxides in mass\%. Single zeros denote the elements below detection limits. 
Nuclear Instruments and Methods in Physics Research B 311 (2013) 53-59

\begin{tabular}{|c|c|c|c|c|c|c|c|c|c|c|c|c|c|c|c|c|}
\hline & & & La & $\mathrm{Ce}$ & $\operatorname{Pr}$ & $\mathrm{Nd}$ & $\mathrm{Sm}$ & $\mathrm{Eu}$ & $\mathrm{Gd}$ & $\mathrm{Tb}$ & Dy & Ho & $\mathrm{Er}$ & $\mathrm{Tm}$ & $Y b$ & Lu \\
\hline 23426 & Lamp & $5-7 c$ & 8 & 13.5 & 1.9 & 7.9 & 1.6 & 0.4 & 1.3 & 0.2 & 1.4 & 0.3 & 0.8 & 0.1 & 0.8 & 0.1 \\
\hline 23069 & Bals. & $5-7 c$. & 6.4 & 11.2 & 1.5 & 6.5 & 1.3 & 0.3 & 1.2 & 0.2 & 1.2 & 0.2 & 0.7 & 0.1 & 0.7 & 0.1 \\
\hline 23078 & Plate & $5-7 . c$ & 5 & 10.7 & 1.3 & 5.1 & 1 & 0.3 & 0.9 & 0.1 & 0.9 & 0.2 & 0.5 & 0.1 & 0.5 & 0.1 \\
\hline 23082 & Goblet & $5-7 . c$ & 6.6 & 12.4 & 1.6 & 6.3 & 1.3 & 0.3 & 1.1 & 0.2 & 1.1 & 0.2 & 0.7 & 0.1 & 0.7 & 0.1 \\
\hline 23033 & Bottle & 4-7c. & 7.3 & 13.6 & 1.8 & 7.5 & 1.5 & 0.4 & 1.4 & 0.2 & 1.4 & 0.3 & 0.8 & 0.1 & 0.9 & 0.1 \\
\hline 23607 & Goblet & $5 . c$ & 5.1 & 9.1 & 1.2 & 5 & 1 & 0.3 & 0.9 & 0.2 & 1 & 0.2 & 0.5 & 0.1 & 0.5 & 0.1 \\
\hline 23030 & Cup & $5-6 . c$. & 4.7 & 8.5 & 1.1 & 4.6 & 0.9 & 0.3 & 0.8 & 0.1 & 0.8 & 0.2 & 0.5 & 0.1 & 0.5 & 0.1 \\
\hline 23054 & Base & $4-5 c$. & 10.8 & 19.3 & 2.5 & 10.9 & 2.2 & 0.5 & 1.9 & 0.3 & 2.3 & 0.4 & 1.3 & 0.2 & 1.4 & 0.2 \\
\hline 23497 & Beaker & $4-5 c$. & 7.5 & 13.3 & 1.7 & 7.3 & 1.5 & 0.4 & 1.4 & 0.2 & 1.2 & 0.2 & 0.7 & 0.1 & 0.7 & 0.1 \\
\hline \multirow[t]{2}{*}{23068} & Beaker & $4-5 c$. & 6.3 & 11.9 & 1.5 & 5.8 & 1.1 & 0.3 & 1 & 0.2 & 1 & 0.2 & 0.6 & 0.1 & 0.6 & 0.1 \\
\hline & & & $\mathrm{Li}$ & B & $\mathrm{P}_{2} \mathrm{O}_{5}$ & $v$ & $\mathrm{Cr}$ & As & $Y$ & $\mathrm{Nb}$ & In & $\mathrm{Ba}$ & $\mathrm{Hf}$ & $\mathrm{Ta}$ & Th & u \\
\hline 23426 & Lamp & $5-7 c$. & 6.44 & 172 & 2101 & 33 & 16 & 6 & 7 & 2.5 & 0.2 & 296 & 2.1 & 0.2 & 1.4 & 1.2 \\
\hline 23069 & Bals. & $5-7 c$. & 3.12 & 206 & 770 & 26 & 12 & 4.2 & 7 & 1.9 & 0 & 333 & 1.6 & 0.1 & 1.1 & 1.3 \\
\hline 23078 & Plate & $5-7 . c$ & 2.52 & 94 & 1062 & 11 & 9 & 2.5 & 5 & 1.2 & 0 & 271 & 0.7 & 0.1 & 0.6 & 0.6 \\
\hline 23082 & Goblet & $5-7 . c$ & 3.23 & 169 & 728 & 21 & 13 & 4 & 6 & 2.2 & 0 & 256 & 1.7 & 0.1 & 1.2 & 1.1 \\
\hline 23033 & Bottle & $4-7 \mathrm{c}$. & 1.28 & 94 & 738 & 25 & 11 & 2.9 & 6 & 1.7 & 0 & 310 & 1.5 & 0.1 & 1 & 1.2 \\
\hline 23607 & Goblet & $5 . c$ & 4.6 & 195 & 1262 & 21 & 37 & 2.5 & 7 & 3.2 & 0.1 & 180 & 3.6 & 0.2 & 1.5 & 1.4 \\
\hline 23030 & Cup & 5-6.c. & 2.51 & 116 & 465 & 17 & 9 & 2.7 & 5 & 1.2 & 0 & 197 & 1.1 & 0.2 & 0.8 & 0.8 \\
\hline 23054 & Base & $4-5 c$. & 2.37 & 160 & 373 & 18 & 10 & 3.5 & 5 & 1.1 & 0 & 183 & 0.9 & 0.1 & 0.6 & 0.9 \\
\hline 23497 & Beaker & $4-5 c$ & 2.35 & 158 & 542 & 52 & 63 & 5 & 11 & 5.4 & 0.1 & 976 & 7.7 & 0.4 & 2.6 & 1.6 \\
\hline 23068 & Beaker & $4-5 c$. & 3.52 & 142 & 1248 & 26 & 13 & 6 & 7 & 2.4 & 0.1 & 275 & 1.9 & 0.2 & 1.3 & 1 \\
\hline
\end{tabular}

Table 3

Elemental or oxide concentrations (in $\mu \mathrm{g} / \mathrm{g}$ ) that were only detected by LA-ICP-MS; rare earths (top) and several others (below). 